\title{
PENERAPAN MODEL MASYARAKAT BELAJAR TERSTRUKTUR DALAM PERKULIAHAN PRAKTIK INSTALASI TENAGA LISTRIK JURUSAN TEKNIK ELEKTRO
}

\author{
Oleh : \\ I Gede Ratnaya \\ Jurusan Teknik Elektronika, FTK, Undiksha
}

\begin{abstract}
ABSTRAK
Pelaksanaan mata kuliah Praktek Tenaga Listrik mahasiswa jurusan D3 Teknik Elektro mengalami beberapa kendala, di antaranya adalah tidak adanya obyek nyata dan waktu yang cukup untuk menambah keahlian berkarya atau keterampilan mahasiswa. Selama ini pelaksanaan praktek hanya dilakukan pada papan simulasi saja sehingga penguasaan praktek di lapangan sangat rendah. Untuk mengantisifasi hal tersebut maka dilakukan penelitian tindakan kelas dengan metode Masyarakat Belajar Terstruktur (MBT) dimana metode ini adalah salah satu ciri dari metode kontekstual. Metode MBT ini mengedepankan mekanisme praktek mahasiswa di lapangan untuk bisa menjawab pertanyaan berupa tugas yang diberikan pada akhir pelaksanaan praktek di kampus. Tugas diberikan sedemikian rupa sehingga untuk menjawab pertanyaan tugas tersebut mahasiswa harus praktek di lapangan terlebih dahulu melalui bimbingan praktisi. PTK ini dilaksanakan dengan dua siklus. Pada siklus II terjadi perubahan yang positif dari siklus I yaitu penguasaan mahasiswa terhadap materi praktek instalasi tenaga listrik dengan katagori kurang dan cukup mengalami penurunan masing masing 4,4 \% dan $8 \%$ sedangkan katagori baik dan memuaskan terjadi peningkatan masing-masing $8 \%$ dan $5 \%$ dari siklus pertama. Temuan tambahan juga didapat oleh mahasiswa seperti timbulnya semangat kewirahusaan di bidang elektro dan pengetahuan yang berupa soft skill yang menimbulkan rasa percaya diri sebagai tenaga kerja yang profesional (siap pakai di lapangan)
\end{abstract}

Kata kunci : Mahasiswa, Praktek Tenaga Listrik, dan Masyarakat Belajar Terstruktur.

\begin{abstract}
Execution of university student D3 Teknik Elektro experience some constraint, among other things inexistence of real obyek and the time which is last for adding student skill. During the time the execution practice only done at board of just simulation so that the domination
\end{abstract}


practice very low at real object. For solutions its done by research of class action with Learning Community Structured (Masyarakat Belajar Terstruktur or MBT) which this method is one of characteristic from Contextual method. Method of this MBT place forward mechanism practice student in real object field to be able reply question in the form of duty at final of execution practice in campus. To answer question of the duty student have to practice in real object beforehand through practitioner tuition. This PTK is executed with two cycle. At cycle II happened by the change which are positive from cycle I that is student domination to items praktek instalasi tenaga listrik by katagori less and enough experience of degradation masing masing $4,4 \%$ and $8 \%$ while good katagori and gratify happened by improvement of each $8 \%$ and $5 \%$ from first cycle. Additional finding also got by student like incidence spirit of interpreneur at electro knowledge and which is in the form of soft skill generating to feel self confidence as professional labour ( ready for use real object).

Key words : student, Practice of Electro Power, and Learning Community Structured

\section{PENDAHULUAN}

Pelaksanaan perkulilahan mata kuliah praktek instalasi tenaga listrik pada jurusan D3 Teknik Elektro Undiksha Singaraja mengalami beberapa kendala, di antaranya adalah tidak adanya objek nyata dan waktu yang cukup untuk menambah keahlian berkarya atau keterampilan mahasiswa. Selama ini pelaksanaan praktek hanya dilakukan pada papan simulasi saja sehingga penguasaan praktek di lapangan sangat rendah, hal ini dibuktikan dengan adanya keluhan para praktisi di lapangan saat mahasiswa melakukan Praktek Kerja Lapangan yang disampaikan kepada dosen pembimbing lapangan.

Sementara itu, teori belajar kontekstual memfokuskan pada banyak aspek dari lingkungan belajar, apakah sekolah, laboratorium, bengkel maupun kebun percobaan. Teori ini mendorong guru untuk memiliki dan mendesain lingkungan belajar yang menggabungkan sebanyak mungkin pengalaman yang berbeda-beda, sosial, budaya, fisik dan psikologis. Dalam lingkungan yang demikian anak didik menemukan hubungan yang bermakna antara ide abstrak dan aplikasi praktis di 
konteks dunia nyata, konsep internalisasi melalui proses penemuan, penguatan dan pengaitan. Hal ini sejalan dengan konsep Masyarakat Belajar yang merupakan ciri dari konsep belajar kontekstual. Konsep ini menyarankan agar hasil pembelajaran diperoleh dari kerjasama, berbicara, dan berbagi pengalaman dengan orang lain. Hasil belajar diperoleh dari sharing antar teman, antar kelompok, di ruang kelas, di sekitar sekolah, juga orang di luar sekolah adalah semua anggota masyarakat belajar sehingga perlu dilakukan usaha-usaha nyata yang dapat menjembatani mereka belajar dari yang sepenuhnya bertumpu pada dosen sebagai sumber belajar menuju pada penggunaan sumber belajar lain. Oleh karena itu, dalam perkuliahan ini dikembangkan sebuat model masyarakat belajar yang dikombinasikan dengan metode kuliah, model tersebut diberi nama model Masyarakat Belajar Terstruktur (MBT).

Adapun rumusan permasalahan yang ingin dipecahkan sesuai dengan latar belakang di atas adalah bagaimana pengaruh penerapan model Masyarakat Belajar Terstruktur terhadap hasil belajar dan keahlian berkarya atau keterampilan mahasiswa di lapangan tentang instalasi tenaga listrik.

\subsection{Teori Belajar Konstruktivistik}

Menurut teori belajar konstruktivistik, belajar merupakan proses pengembangan pengetahuan yang telah dimiliki sebelumnya. Pengembangan pengetahuan terjadi melalui proses interaksi antara pengetahuan yang telah dimiliki pebelajar sebelumnya dengan pengetahuan atau pengalaman yang baru diperoleh (Fosnot, 1989, 1996). Menurut Piaget, proses interaksi tersebut belangsung dalam tiga tahapan, yaitu tahap penerimaan/pemasukan informasi (asimilasi), tahap penyesuaian informasi baru dengan pengetahuan yang telah dimiliki (akomudasi) dan tahap menyetimbangan pengetahuan (ekuilibrasi). Keadaan kesetimbangan yang harus merupakan wujud dari kemajuan belajar. Proses ini terjadi secara berkelanjutan sepanjang hayat. 
Kemampuan seorang pebelajar untuk mengkonstruksi pengetahuan baru ditentukan oleh tingkat perkembangan mental (kognitif) dan tingkat perkembangan sosial. Menurut Piaget, proses belajar anak ditentukan oleh tingkat perkembangan mentalnya (Lawson, 1995). Tahapan perkembangan mental anak dari usia nol hingga 15 tahun dibedakan menjadi empat tahapan, yaitu tahap perkembangan sensorymotor (usia 0-18 bulan), tahap perkembangan preoperational (usia 18 bulan - 7 tahun), tahap perkembangan concrete operational (usia 7-11 tahun) dan tahap perkembangan formal operational (usia 11-15 tahun). Lain halnya dengan Piaget, Vygotsky menyatakan bahwa proses belajar anak berkaitan dengan tingkat perkembangan sosialnya. Dalam hal ini, lingkungan sosial tempat anak-anak berinteraksi ikut menentukan perkembangan proses belajarnya. Dinyatakan bahwa anak-anak akan dapat belajar secara optimal jika berada dekat dengan daerah perkembangannya yang dikenal dengan Zone of Proxima/ Development (Vygotsky, 1978). Menurut pandangan Vygotsky, pengetahuan dibangun melalui kesesuaian budaya dan interaksi sosial antara anak dengan teman bergaulnya yang lebih kompeten. Contoh pengunaan bahasa sebagai media komunikasi yang memfasilitasi perkembangan kecerdasannya (Howe, 1996). Howe (1996) menyatakan bahwa walaupun Piaget dan Vygotsky menjelaskan perkembangan anak dari sudut pandang yang berbeda, namun keduanya menganut pandangan konstruktivistik. Berdasarkan kedua pandangan tersebut, maka dapat dinyatakan bahwa "proses belajar akan dipengaruhi oleh interaksi pebelajar dengan lingkungan belajarnya termasuk instruksi atau fasilitas yang diberikan dosen".

\subsection{Teori Masyarakat Belajar}

Menurut teori belajar kontekstual, belajar terjadi hanya ketika siswa memproses informasi maupun pengetahuan baru sedemikian rupa sehingga informasi tersebut beradaptasi dengan kerangka acuan mereka. 
Pendekatan ini menganggap bahwa fikiran manusia secara alamiah mencari makna dalam suatu konteks, yaitu berkaitan dengan lingkungan seseorang.

Kurikulum dan pengajaran yang berbasis strategi ini disusun untuk memungkinkan terjadi lima bentuk belajar yang penting yaitu : mengaitkan (relating), mengalami (experiencing), menerapkan (applying), bekerja sama (cooperating) dan mentransfer (transferring).

\subsection{Teori Belajar Orang Dewasa}

Cara belajar orang dewasa berbeda dengan anak-anak. Anakanak di sekolah belajar sesuai dengan apa yang disuruh atau yang dituntut oleh kurikulum. Dengan demikian peran guru dalam pembelajaran anak (pedagogi) sangat esensial. Dalam pembelajaran anak (sekolah), guru berperan untuk menentukan isi materi pelajaran, cara belajar anak, dan waktu belajarnya (Burns. 1995).

Menurut Albert Bandura (1977, dalam Burns 1995), ada dua unsur utama dalam proses belajar, yaitu pengalaman (experience) dan harapan (expectation). Dinyatakan bahwa pengalaman akan melahirkan konsekuensi dari sebuah tindakan dan harapan akan melahirkan antisipasi terhadap akibat dari sebuah tindakan. Teori belajar ini memberikan ilham pengembangan model belajar kelompok. Pengaruh belajar kelompok terhadap individu dijelaskan dalam tahapan proses belajar yang terdiri atas perhatian (attention), ketahanan atau retensi (retention), perbuatan (reproduction), dan penguatan (reinforcement). Perhatian berhubungan dengan keadaan objek pelajaran, misalnya, keindahan, kesuksesan, pengulangan dan lain-lain. Ketahanan berhubungan dengan seberapa lama model ini memberikan pengaruh terhadap individu. Perbuatan menyangkut seberapa jauh pebelajar mampu menirukan perilaku yang ada dan yang dimaksudkan. Penguatan berhubungan dengan motivasi yang diperoleh setelah melakukan suatu perbuatan. 


\section{METODE}

Beberapa aspek penting pelaksanaan penelitian yang dipandang perlu untuk dipaparkan adalah tempat pelaksanaan pembelajaran, karakteristik mata kuliah, subjek atau pebelajar (mahasiswa) yang terlibat, metode pembelajaran, penilaian hasil belajar pembelajaran, analisis temuan dan laporan hasil.

\subsection{Objek dan Subjek Penelitian}

Penelitian ini akan dilaksanakan pada mata kuliah Praktek Instalasi Tenaga Listrik yang dilkuti oleh mahasiswa semester V Jurusan Teknik Elektro Undiksha Singaraja tahun akademik 2005/2006 sebanyak 23 orang dan melibatkan beberapa praktisi (instalatir) yang ada di sekitar kota singaraja. Lokasi pelaksanaannya berada pada ruang kelas, workshop jurusan teknik elektro Undiksha, dan dilapangan di sekitaran kota singaraja.

Mata kuliah Praktek Instalasi Tenaga Listrik terdiri atas beberapa pokok bahasan pemeriksaan, pemahaman, pengujian, perencanaan dan pelaksanaan yang meliputi : 1) Instalasi rumah tinggal, 2) Instalasi gedung sekolah, 3) Instalasi gedung bertingkat, 4) Instalasi bengkel kerja dengan mempertimbangkan kompetensi-kompetensi yang diharapkan oleh praktisi.

\subsection{Pelaksanaan Penelitian}

Ada 2 (dua) siklus yang dilakukan dalam penelitian ini yang masing-masing siklus terdiri atas 4 (empat) tahapan yaitu rencana tindakan, pelaksanaan tindakan, evaluasi, dan refleksi.

Pada siklus pertama, rencana tindakan terdiri-dari sosialisasi penelitian, persiapan bahan ajar, pencarian para praktisi yang mungkin bisa diajak kerjasama, dan pendataan kompetensi-kompetensi yang diharapkan oleh praktisi. Tahap pelaksanaan tindakan terdiri-dari pemberian kuliah di kelas dengan materi instalasi rumah tinggal dan 
gedung sekolah, praktek di workshop, dan praktek di lapangan dengan bimbingan praktisi. Tahapan evaluasi terdiri-dari observasi terhadap mahasiswa di kelas, di workshop, dan di lapangan, serta pengevaluasian terhadap laporan mahasiswa, seminar, hasil ujian praktek, dan hasil penilaian praktisi. Tahapan refleksi terdiri-dari pengidentifikasian hambatan-hambatan pelaksanaan penelitian ini dan pencarian solusinya yang dapat dijadikan acuan untuk pelaksanaan siklus berikutnya.

Pada siklus kedua, rencana tindakan terdiri-dari, persiapan bahan ajar, dan pendataan kompetensi-kompetensi yang diharapkan oleh praktis. Tahap pelaksanaan tindakan terdiri-dari pemberian kuliah di kelas dengan materi instalasi gedung bertingkat dan instalasi bengkel kerja, praktek di workshop, dan praktek di lapangan dengan bimbingan praktisi. Tahapan evaluasi terdiri-dari observasi terhadap mahasiswa di kelas, di workshop, dan di lapangan, serta pengevaluasian terhadap laporan mahasiswa, seminar, hasil ujian praktek, dan hasil penilaian praktisi. Tahapan refleksi terdiri-dari pengidentifikasian hambatanhambatan pelaksanaan penelitian ini dan pencarian solusinya.

Ada tiga metode yang akan digunakan dalam penerapan MBT pada penelitian ini yang terimplikasi pada tahapan pelaksanaan tindakan yaitu: 1) metode perkuliahan di kelas dan praktek. Setiap pokok bahasan teori pendahuluan dan praktek sebatas peralatan yang tersedia di workshop. Dalam pembelajaran, dosen menyampaikan gambaran umum materi. Pokok-pokok materi kuliah ini dibantu dengan materi ajar yang dipersiapkan dosen. 2) metode tugas terstruktur, metode tugas yang digunakan dosen dalam memberikan tugas-tugas instruksional terstruktur kepada mahasiswa. Dalam hal ini, tugas mahasiswa diberikan secara berkelompok dan mahasiswa diberikan keleluasaan untuk menentukan anggota kelompoknya. Tugas dibuat dalam bentuk laporan yang siap untuk diseminarkan di kelas, dalam pembuatan tugas, dosen bekerjasama dengan beberapa praktisi (instalatir) untuk memberikan fasilitas dalam pengerjaan tugas tersebut, dan 3) metode seminar, metode seminar yang 
digunakan dosen untuk memperoleh pertanggungjawaban mahasiswa terhadap tugas-tugas yang diberikan dan memacu mahasiswa berbicara dalam Seminar. Dalam seminar, tiap-tiap kelompok akan ditampilkan secara utuh di depan kelas dan anggota kelompok diberikan kebebasan untuk mengatur diri dalam penyampaian tugas dan temuannya. Setelah presentasi dilanjutkan dengan diskusi kelas untuk menampung segala bentuk pertanyaan dan tanggapan kelas serta klarifikasi dari anggota kelompok.

\subsection{Penilaian Hasil Pembelajaran}

Ada lima bentuk penilaian yang dilakukan dalam pelaksanaan pembelajaran di atas, yaitu penilaian tugas secara tertulis, penilaian pemaparan hasil dan argumentasi, penilaian partisipasi dalam seminar serta penilaian ujian praktek nilai yang diberikan oleh praktisi. Penilaian tugas secara tertulis merupakan penilaian kerja kelompok. Nilai tugas tertulis diberikan sama untuk setiap anggota kelompok. Penilaian pemaparan hasil dan argumentasi diberikan kepada mereka yang memberikan kontribusi yang sesuai dengan topik kajian/paparan. Penilaian partisipasi mahasiswa dalam seminar diberikan kepada mereka yang berpartisipasi dengan mempertimbangkan kualitas partisipasinya. Penilaian ujian praktek digunakan untuk menilai penguasaan mahasiswa terhadap materi kuliah yang dipelajari dengan model MBT. Ujian praktek yang dimaksud adalah hasil ujian tengah semester (UTS) dan ujian akhir semester (UAS) yang meliputi hasil penilaian praktisi dan dosen pengajar.

\subsection{Analisis Hasil Pembelajaran}

Semua temuan yang diperoleh dalam implementasi program ini dianalisis secara deskriptif menggunakan pemetaan prosentase yang menerangkan hasil belajar dan kemampuan berkarya atau keterampilan mahasiswa di lapangan. Dalam menginterpretasi hasil pembelajaran 
pembelajar (pelaksana) menggunakan rekaman data berupa tugas-tugas mahasiswa, presentasi mahasiswa, partisipasi atau diskusi selama proses seminar, hasil ujian tengah semester dan hasil ujian akhir semester. Nilainilai tersebut diolah dari skor 0 sampai 100 dengan standar patokan mengikuti buku pedoman studi dengan rincian dengan perincian sebagai berikut :

Tabel 1 Hubungan Skor dan Nilai Akhir

\begin{tabular}{|c|c|c|}
\hline No & Rentangan Skor & Nilai Akhir \\
\hline 1 & $85-100$ & A \\
\hline 2 & $70-84$ & B \\
\hline 3 & $55-69$ & C \\
\hline 4 & $40-54$ & D \\
\hline 5 & $0-39$ & E \\
\hline
\end{tabular}

( Sumber Pedoman Studi Undiksha, 2006)

\section{PEMBAHASAN}

Hasil penelitian yang dikemukakan disini mencakup pelaksanaan penelitian, hasil penelitian, dan pembahasan hasil penelitian. Pelaksanaan penelitian meliputi pelaksanaan tindakan pada siklus I dan siklus ke II yang di dalamnya tercakup : 1) Perencanaan berupa persiapan-persiapan sebelum tindakan di lakukan ,2) Pelaksanaan tindakan yaitu metode perkuliahan dan praktek di workshop dan dilapangan, seminar, 3) Hasil observasi, dan 4) evaluasi dan refleksi. Hasil penelitian diulas pada bagian observasi karena pelaksanaan dan observasi berlangsung secara bersamaan. Bagian pembahasan menganalisis hasil penelitian siklus I dan siklus II secara deskriptif prosentase.

Setelah tindakan dilakukan didapatkan hasil sesuai tabel 2 dan tabel 3. 
Tabel 2 Prosentase penilaian mahasiswa pada siklus I

\begin{tabular}{|c|c|c|c|c|}
\hline \multirow[b]{2}{*}{ Jenis Penilaian } & \multicolumn{4}{|c|}{ Prosentase Nilai } \\
\hline & $\begin{array}{l}\text { Kurang } \\
\text { (skor 0-54) }\end{array}$ & $\begin{array}{l}\text { Cukup } \\
\text { (skor 55- } \\
69 \text { ) }\end{array}$ & $\begin{array}{l}\text { Baik } \\
\text { (skor 70- } \\
84 \text { ) }\end{array}$ & $\begin{array}{l}\text { Memuaskan } \\
\text { (skor 85-100) }\end{array}$ \\
\hline Laporan (Tugas Tulis) & - & - & - & $100 \%$ \\
\hline Praktek di workshop & $30,4 \%$ & $52,2 \%$ & $17,4 \%$ & - \\
\hline $\begin{array}{lll}\text { Praktek di Lapangan } \\
\text { hari } & & \\
\text { Kedua } & & \\
\end{array}$ & $21,7 \%$ & $69,6 \%$ & $8,7 \%$ & - \\
\hline $\begin{array}{lr}\text { Pemaparan } & \text { hasil } \\
\text { Kelompok } & \text { dlm } \\
\text { Seminar } & \\
\end{array}$ & - & $8,7 \%$ & $69,6 \%$ & $21,7 \%$ \\
\hline $\begin{array}{l}\text { Argumentasi dan } \\
\text { partisipasi dlm seminar }\end{array}$ & - & $8,7 \%$ & $82,6 \%$ & $8,7 \%$ \\
\hline Ujian praktek & - & $56,5 \%$ & $21,7 \%$ & $21,7 \%$ \\
\hline
\end{tabular}

Tabel 3 Hasil penilaian terhadap mahasiswa pada siklus II

\begin{tabular}{|l|c|c|c|c|}
\hline \multirow{2}{*}{ Jenis Penilaian } & \multicolumn{4}{|c|}{ Prosentase Nilai } \\
\cline { 2 - 5 } & $\begin{array}{l}\text { Kurang } \\
\text { (skor 0-54) }\end{array}$ & $\begin{array}{l}\text { Cukup } \\
\text { (skor 55- } \\
69)\end{array}$ & $\begin{array}{l}\text { Baik } \\
\text { (skor 70- } \\
84)\end{array}$ & $\begin{array}{l}\text { Memuaskan } \\
\text { (skor 85-100) }\end{array}$ \\
\hline Laporan (Tugas Tulis) & - & - & - & $100 \%$ \\
\hline Praktek di workshop & $17,4 \%$ & $47,8 \%$ & $34,8 \%$ & - \\
\hline $\begin{array}{l}\text { Praktek di Lapangan } \\
\text { hari } \\
\text { Kedua }\end{array}$ & $4,3 \%$ & $69,6 \%$ & $26,1 \%$ & - \\
\hline $\begin{array}{l}\text { Pemaparan helompok dlm } \\
\text { Kelominar } \\
\text { Semilasi dan }\end{array}$ & - & $8,7 \%$ & $69,6 \%$ & $21,7 \%$ \\
\hline $\begin{array}{l}\text { Argumentasi } \\
\text { partisipasi dlm seminar }\end{array}$ & - & $8,7 \%$ & $69,6 \%$ & $21,7 \%$ \\
\hline \multicolumn{2}{|l|}{ Ujian Praktek } & $13 \%$ & $47,8 \%$ & $39,1 \%$ \\
\hline
\end{tabular}

Perbandingan hasil penilaian yang didapat pada siklus I dan siklus II disajikan pada tabel 4. Penilaian ini mencakup hasil penilaian rata-rata dari laporan mahasiswa, praktek di workshop, praktek di lapangan, dan seminar (pemaparan hasil kelompok, argumentasi, dan partisipasi).

Tabel 4 Perbandingan hasil penilaian siklus I dan siklus II

\begin{tabular}{|l|c|c|}
\hline \multicolumn{1}{|c|}{ Katagori } & Prosentase siklus I & Prosentase siklus II \\
\hline Kurang (skor 0 - 54) & $8,7 \%$ & $4,3 \%$ \\
\hline Cukup (skor 55-69) & $32,6 \%$ & $24,6 \%$ \\
\hline Baik (skor 70 -84) & $33,3 \%$ & $41,3 \%$ \\
\hline Memuaskan (skor 85-100) & $25,4 \%$ & $30,4 \%$ \\
\hline
\end{tabular}

JPTK, UNDIKSHA, Vol. 6, No. 2, Juli 2009 : 1 - 12 
Pada tabel 4 diperlihatkan bahwa terjadi perubahan penguasaan materi praktek instalasi tenaga listrik, dimana katagori kurang dan cukup mengalami penurunan masing masing $4,4 \%$ dan $8 \%$ sedangkan katagori baik dan memuaskan terjadi peningkatan masing-masing $8 \%$ dan $5 \%$.

Kalau dibandingkan dengan refleksi awal yang melatarbelakangi penelitian ini, tindakan seperti ini sangat tepat dilakukan pada mata kuliah praktek instalasi tenaga listrik, namun hal ini sangat tergantung kepada situasi dan kondisi proyek yang sedang digarap oleh praktisi yang diajak kerjasama. Pengalaman yang didapatkan oleh mahasiswa tidak terbatas pada meteri kuliah saja tetapi juga di luar materi kuliah tetapi masih dalam cakupan materi kuliah jurusan teknik elektro, seperti pengetahuan tentang jaringan listrik tegangan menengah dan komponenkomponennya.

Temuan tambahan juga didapat oleh mahasiswa seperti timbulnya semangat kewirahusaan di bidang elektro dan pengetahuan yang berupa soft skill yang menimbulkan rasa percaya diri sebagai tenaga kerja yang profesional (siap pakai di lapangan).

\section{SIMPULAN}

Berdasarkan hasil analisis data dan temuan-temuan yang diperoleh dari penelitian ini dapat ditarik kesimpulan sebagai berikut : 1) Berdasarkan refleksi awal yang melatarbelakangi tindakan ini dan kedua siklus yang telah dilaksanakan secara umum terjadi peningkatan keterampilan mahasiswa. 2) Keterampilan mahasiswa di bidang instalasi tenaga listrik sangat dipengaruhi oleh pengalaman nyata mahasiswa di lapangan. 3) Pengalaman nyata mahasiswa dilapangan melibatkan komponen luar kampus sebagai sumber belajar dalam pembelajaran mahasiswa. Komponen luar kampus tersebut adalah para praktisi. 4) Dalam pelaksanaan tindakan pembelajaran di luar kampus, terjadi sharing pengetahuan antara mahasiswa dan praktisi, namun lebih banyak pengetahuan itu dari praktisi ke mahasiswa. 5) Untuk mendapatkan 
pengetahuan di lapangan yang cukup sangat tergantung dari kemampuan mahasiswa berkomunikasi dengan praktisi dan masyarakat. 6) Respon mahasiswa terhadap pembelajaran praktek instalasi tenaga listrik yang melibatkan komponen luar kampus (model masyarakat belajar tersetruktur) sangat baik dan malah sangat diharapkan oleh mahasiswa.

\section{DAFTAR PUSTAKA}

Burns, R. 1995, The Adult learner at Work. Australia: Business \& Profession.

Ekohariadi, 2003, Modalitas Majemuk Pada Pembelajaran Kontekstual. Departemen Pendidikan Nasional, Direktorat Jenderal Pendidikan Dasar dan Menengah, Direktorat Pendidikan Lanjutan Pertama.

Fosnot, C. T. 1989. Inquiring Teachers Inquiring Learners: A Constructivist Approach for Teaching. New York: Teacher College Press.

Fosnot, C. T, 1996. Contructivism: Theory'Perspectives, and Practice. New York. Teacher College Press.

Howe, A. C. 1996. Development of Science Concepts within a Vygotskian Framework, Science Education. 80 ( 1 ) :35-51.

Universitas Pendidikan Ganesha. 2006. Pedoman Studi Universitas Pendidikan Singaraja Tahun 2002 Edisi Fakultas Pendidkan Teknologi dan Kejuruan Singaraja. Universitas Pendidikan Ganesha Singaraja.

Lawson, A. E. 1995. Science Teaching and $T$ he Development of Thinking. Belmont, California: Wadsworth Publishing Company.

Wahono, 2002, Pengajaran Dan Pembelajaran Kontekstual (CTL). Departemen Pendidikan Nasional, Direktorat Jenderal Pendidikan Dasar dan Menengah, Direktorat Pendidikan Lanjutan Pertama. 